\title{
Soft Tissue Infection after Missile Injuries to the Extremities-A Non-Randomized, Prospective Study in Gaza City
}

\author{
Hazem M. Hamouda, MD; ${ }^{1}$ Eivind Witsø, PhD ${ }^{2}$ Nedal K.E. Moghani, MD; ${ }^{1}$ \\ Ahmed Shahwan, $\mathrm{PhD} ;{ }^{3}$ Øystein P. Nygaard, $\mathrm{PhD}^{2}$
}

1. Palestinian Red Crescent Society, Al Quds Hospital, Tel Al Hawa, Gaza City, Gaza Palestinian Authority

2. St. Olavs University Hospital, Norweigan University of Science and Technology, Trondheim, Norway

3. Palestinian Red Crescent Society, Balsam Hospital, Medical Services, Beit Lahia, Gaza Palestinian Authority

\author{
Correspondence: \\ Dr. Eivind Witsø \\ Department of Orthopedic Surgery \\ St. Olavs University Hospital \\ 7006 Trondheim \\ Norway \\ E-mail: eivind.witso@stolav.no
}

Keywords: antibiotics; extremity injuries; infection; Gaza City; missile injuries; soft tissue infection

\section{Abbreviations: \\ None}

Received: 28 April 2006

Accepted: 12 May 2006

Revised: 20 June 2006

Web publication: 27 April 2007

\begin{abstract}
Introduction: Patients with soft tissue injuries caused by missile attacks during wartime have been treated with radical debridement and delayed closure. In a study in Gaza City, the rate of infection of missile injuries to the extremities when treated with minimal surgical intervention, was measured.

Methods: Patients with severe soft tissue damage, compound fractures, and injuries to major blood vessels and/or nerves were excluded from the study. One hundred fourteen patients were treated according to a standardized regime that included a superficial, minor surgery revision of the inlet and the outlet opening, and antibiotic treatment. Local soft tissue infection was defined as the presence of at least two signs of local infection.

Results: A total of 109 out of 114 patients attended the first follow-up visit. Eleven (10\%) of these patients had an infected wound. A total of 105 of the patients $(92 \%)$ attended a second follow-up. None of these patients had an infected wound.

Conclusions: Under conditions with a high number of causalities, minimal surgical treatment followed by the administration of antibiotics is a safe procedure for patients with penetrating missile injuries and less severe soft tissue damage.
\end{abstract}

Hamouda HM, Witsø E, Moghani NKE, Shahwan A, Nygaard ØP: Soft tissue infection after missile injuries to the extremities-A non-randomized, prospective study in Gaza City. Prehosp Disast Med 2007:22(2)106-108.

\section{Introduction}

Penetrating soft tissue injuries caused by missiles are treated differently during times of war and peace. Civilian gunshot wounds causing a low-energy injury to the skin, subcutaneous tissue, and/or muscle are treated with minimal or no surgical intervention, while high-energy injuries with significant tissue damage are treated operatively. ${ }^{1-5}$ However, in times of war, it is advocated that both low- and high-energy missile injuries be treated with exploration, radical debridement, drainage, and delayed primary closure.$^{6-9}$ During wartime, missile wounds can be heavily contaminated, the number of causalities can be large, the working conditions may be poor, and the staff may have limited experience. ${ }^{7}$ It has been stated that the civilian approach to these injuries should not be transferred to the bartlefield. In times of war, every part of the missile wound should be explored, debrided, and left open for delayed closure.

During the first years of the second Palestinian uprising (Intifada), which started in November 2000, thousands of people were injured by missiles. Several of these patients were treated in temporary hospitals under circumstances similar to those during wartime. However, several of the patients with extremity injuries were treated with a conservative approach, similar to what is common when treating civilian gunshot injuries. In a non-randomized, prospective study, the results of minimal surgical treatment of soft tissue missile injuries to the extremities on patients who were submitted to Al Quds (temporary) Hospital in Gaza City were evaluated.

\section{Methods}

The study was designed as a prospective study in Gaza City, Palestinian Authority to be performed 01 January 2001 to 01 January 2003.

http://pdm.medicine.wisc.edu

Vol. 22, No. 2 


\begin{tabular}{|l|c|}
\hline \multicolumn{1}{|c|}{ Injury type/location } & $\begin{array}{c}\text { Number of injuries } \\
\mathbf{n = 1 1 4}(\%)\end{array}$ \\
\hline Arm & $28(25)$ \\
\hline Hand & $10(9)$ \\
\hline Thigh & $34(30)$ \\
\hline Knee & $6(5)$ \\
\hline Leg & $25(22)$ \\
\hline Foot & $\mathbf{1 1}(10)$ \\
\hline
\end{tabular}

Table 1-Anatomical distribution of missile injuries in 114 patients. Two-thirds of the injuries were located in the lower extremities.

All patients who were referred to Al Quds, the Palestinian Red Crescent Society Hospital in Gaza City, were evaluated for participation in the study. Patients 10-50 years of age who had sustained missile injuries to one of the extremities were included in the study. The interval from time of injury to time of treatment had to be $<6$ hours. Those excluded from the study included patients with: (1) inlet and/or outlet openings of $>2.5 \mathrm{~cm}$; (2) compound fractures; (3) injuries to major blood vessels or nerves; (4) penetrating injuries to the brain, thorax, abdomen, or pelvis; (5) using antibiotics or immune-suppressive drugs at the time of the injury; (6) systemic disease (e.g., diabetes mellitus); and/or (7) homes outside of the Gaza Strip.

One of two surgeons examined all participants in the study. Systolic blood pressure, level of consciousness, and mental responses were registered according to a standard formula. Peripheral circulation and nerve function of the injured extremity also were registered.

The standardized treatment included: (1) cleaning the wound with iodine and saline; (2) superficial, minor surgery that included revising the inlet and outlet openings; (3) removing easily accessible retained fragments; and (4) cleaning the wound daily until that wound secretion was stopped. Cephalexine, $500 \mathrm{mg} \times 4$ and metronidazol, $500 \mathrm{mg} \mathrm{x} 3$ were administered intravenously for two days. This was followed by the oral administration of cephalexine, $500 \mathrm{mg} \mathrm{x} 4$ and metronidazol, $\mathrm{mg} 250 \times 3$ for three days. One-half of an adult dose was given to patients $<14$ years of age. All of the patients received a booster dose of tetanus toxin.

At seven days and six weeks after treatment, the patients were examined by the surgeon. At the follow-up visit, local soft tissue infection was defined as the presence of at least two local signs of infection (erythema, swelling, pain, and/or purulent secretion). According to the evaluation of the surgeon, the local signs of infection should be significant enough to warrant antibiotic treatment.

This study was approved by the Palestinian Red Crescent Society, Ramallah, West Bank, Palestinian Authority.

\section{Results}

One hundred fourteen patients (102 males and 12 females, $22 \pm 9$ years of age) were included in the study. All of the patients were inhabitants of Gaza City. If not otherwise stated, data are presented as given as the mean value \pm 1 standard deviation. The time interval from the time of injury to the time of primary treatment was $29 \pm 11 \mathrm{~min}$ utes (maximum 60 minutes). All patients included in the study had a normal systolic blood pressure and a normal level of mental response. The anatomic distribution of the missile injuries is listed in Table 1. For 112 patients (98\%), the inlet-opening was $1.0 \mathrm{~cm}$ (total range: $0.4-1.6 \mathrm{~cm}$ ). In one patient, the diameter of the inlet opening was not registered, and in another patient, the skin edges were so lacerated that it was not possible to make an exact estimation of the diameter of the inlet-opening. Neither of these patients were considered to have a wound cavity (i.e., inlet opening $>2.5 \mathrm{~cm}$ ). Fifty-three patients $(46 \%)$ had an outlet opening of $1.4 \mathrm{~cm}$ (total range: $0.6-2.5 \mathrm{~cm}$ ). In one patient, it was not registered whether or not an outlet opening was present. In another patient, the diameter of the outlet opening was not measured due to a laceration of the edge of the skin. Fifty-nine patients (52\%) did not have an outlet opening. Seven of the patients had a simple fracture. One patient had an injury to the superficial peroneal nerve. The local treatment of the wound was performed according to standardized treatment for all patients. Thirty-eight patients (33\%) had missile fragments removed, and 37 patients (32\%) still had fragments remaining.

A total of 106 patients (93\%) received cephalexine/metronidazol intravenously for two or three days. Eight patients received other antibiotic regimes intravenously (cephalexine, metronidazole/ampicillin, metronidazole/ampicillin/cephalexine, ampicillin/cloxacillin/metronidazole, cehalexine/gentamicine, cephalexine/cloxacilin, ampicillin/cloxacillin). One hundred patients $(88 \%)$ received oral antibiotic treatment with cepohalexine/metronidazole. Fourteen patients (12\%) received an alternative oral antibiotic treatment (metronidazole/ampicillin, cephalexine, cloxacillin). The length of oral administered antibiotics was: (1) three days (77 patients (68\%)); (2) five days (23 patients (20\%)); (3) four days (eight patients (7\%)); and (4) two days (six patients (5\%)). The patients were discharged from the hospital after $3 \pm 1$ days.

A total of 109 (96\%) of the patients were examined during their first follow-up visit $7 \pm 2$ days after sustaining the injury. According to the definition, $11(10 \%)$ of these patients had a local soft tissue infection. Two of these patients (18\%) had purulent secretion, erythema, swelling, and pain; nine patients (81\%) experienced pain, erythema, and/or swelling. Each of these 11 patients received the combination of cephalexine/metronidazol intravenously for two or three days, followed by oral administration for three to five days. Four of the 11 patients $(36 \%)$ had a missile fragment removed, and two patients still had fragments remaining. In the patients without an infection $(\mathrm{n}=98), 35$ (36\%) still had fragments remaining, and $33(43 \%)$ had a missile fragment removed. Nine of the 11 patients (82\%) were treated with antibiotics alone, and two patients were treated with secondary surgical debridement and antibiotics.

A total of 105 (92\%) patients, including the 11 patients who had an infection at the first follow-up visit, were examined at a second follow-up $40 \pm 12$ days after the injury. 
None of these patients had an infection, and none of them reported having had an infection in the interval between their first and second follow-ups.

\section{Discussion}

In this study, only one-third of the patients had a retained missile fragment, which often was deformed. Hence, an exact identification of the weapon responsible for the injury was not possible. According to the Red Cross Classification, war injuries are classified according to wound characteristics, not upon weaponry. A Grade-1 wound does not have a wound cavity. A wound cavity is a cavity that at least two fingers can fit into before wound excision, and there are no comminuted fractures or injuries to vital structures, such as major blood vessels or the central nervous system (CNS). Grade-2 and Grade-3 wounds are wounds with various degrees of wound cavities, comminuted fractures, and injuries to vital structures. ${ }^{10}$

Patients with an inlet and/or outlet opening $>2.5 \mathrm{~cm}$, patients with comminuted fractures, and patients with injuries to major vessels or major nerves were excluded from the study. No patient had any clinical signs of hypovolemia. Therefore, it was concluded that all of the patients included in the study had a Grade-1 wound.

At the first follow-up examination, $10 \%$ of patients had signs of an infection, but no symptoms at the second followup visit. Due to the setting, isolation and identification of the causative organisms were not possible. In addition, the surgeon had to consider the signs of infection as clinically significant and administer antibiotics as needed. In Gaza, the indication for the use of antibiotics is rather liberal. Hence, the registered number of infected cases probably is an overestimate. None of the 11 patients with an infection upon first examination had a severe infection. Only two of these patients needed secondary debridement, and only oral antibiotics were given. This indicates that the infections were superficial.
Civilian gunshot injuries have been treated successfully with limited surgical intervention. The rate of infection has been reported to be between $2 \%$ and $4 \%$, and the rate of infection has not been influenced by antibiotic treatment. ${ }^{1-4}$ In a report from Afghanistan, 15 causalities with Grade-1 wounds were treated conservatively by cleaning and dressing the wound. Penicillin was administered intravenously for one day and orally for four days. As a result, two patients (13\%) developed a superficial abscess. Most of the causalities arrived at the hospital 24 to 48 hours after being wounded. More work must be done in order to identify war wounds that can be treated conservatively. ${ }^{11}$ The Palestinian Red Crescent Society in the Gaza Strip developed an effective infrastructure regarding the evacuation and transportation of injured patients. Therefore, the low infection rate observed in this study may be explained partially by the short time interval from the time of injury to the time of treatment.

\section{Limitations}

This study has several limitations. Further studies should be performed where patients are randomized to different treatment modalities. However, according to the Palestinian Red Crescent Society, several thousand patients with missile injuries were recorded during the study period. Such a large number of injuries places an extremely high burden on the local healthcare system. The results of this study indicate that minimal surgical treatment of missile injuries to the extremities can be used as an alternative treatment in situations with a high number of casualties and limited resources.

\section{Conclusions}

Minimal surgical treatment of missile injuries to the extremities can be used as alternative treatment in situations with a high number of casualties and limited resources.
References

1. Woloszyn JT, Uitvlugt GM, Castle ME: Management of civilian gunshot fractures of the extremities. Clin Ortbop 1988;226:247-251.

2. Dickey RL. Barnes BC, Kearns RJ, Tullos HS: Efficacy of antibiotics in lowvelocity gunshot fractures. J Orthop Trauma 1989;3(1):6-10.

3. Geissler WB, Teasedall RD, Tomasin JD, Hughes JL: Management of low velocity gunshot-induced fractures. J Orthop Trauma 1990;4(1):39-41.

4. Knapp TP, Patzakis MJ, Lee J, Seipel PR, Abdollahi K, Reisch RB: Comparision of intravenous and oral antibiotic therapy in the treatment of fractures caused by low-velocity gunshots. A prospective, randomized study of infection rates. J Bone Joint Surg (Am) 1996;78(8):1167-1171.

5. Bartlett CS: Clinical update: Gunshot wound ballistics. Clin Orthop Relat Res 2003;408:28-57.
6. Coupland RM: Technical aspects of war wound excision. Br J Surg 1989;76(7):663-667.

7. Cooper GJ, Ryan JM: Interaction of penetrating missiles with tissue: Some common misapprehensions and implications for wound management. $\mathrm{BrJ}$ Surg 1990;77:606-610.

8. Husum H, Ang SC, Fosse E: War Surgery. Field Manual. Penang, Malaysia: Third World Network, 1995.

9. Molde $\dot{A}$ : Victims of war. Surgical principles must not be forgotten (again)! Acta Orthop Scand 1998;69(Suppl 281):54-57.

10. Coupland RM: The Red Cross classification of war wounds: The E.X.C.F.V.M. scoring system. World J Surg 1992;16(5):910-917.

11. Bowyer GW: Management of small fragment wounds: Experience from the Afghan border. $/$ Trauma 1996;40(3):s170-s172. 


\title{
Editorial Comment: Soft Tissue Infection after Missile Injuries to the Extremities-A Non-Randomized, Prospective Study in Gaza City
}

\author{
Col. Yaron Bar-Dayan, MD, MHA; ${ }^{1,2}$ Col (res) Prof. Avishay Goldberg, PhD ${ }^{1}$
}

1. Israel Defense Forces Home Front Command, Medical Department, Israel

2. Department of Emergency Medicine, Meir Hospital and the Department of Disaster and Emergency Medicine, and the Department of Healthcare Management, and the Faculty of Health Sciences, Ben Gurion University, BeerSheva, Israel

\author{
Correspondence: \\ Col. Dr. Y. Bar-Dayan MD, MHA \\ 16 Dolev St.
}

Neve Savion, Or-Yehuda, ISRAEL

E-mail: bardayan@netvision.net.il

Web publication: 27 April 2007
In the last decade, hundreds of civilians and soldiers died, and thousands were wounded due to numerous terrorist attacks in Israel. ${ }^{1-3}$ This conflict led to prolonged, low-intensity damage to people and property, which is different than a total war. In the military literature, this is called low-intensity conflict. Lowintensity conflict is not peace and it is not war-the severity and distribution of injuries and principles of the medical response are different. In some incidents, the principles resemble those during a wartime medical responses, and in some incidents, the principles resemble those of peacetime medical responses. In other incidents, the response is unique.

Low-intensity conflict is different from war in several ways: (1) the force is localized; (2) the destructive energy of the weapons is lower; (3) the number of casualties per day is lower; (4) the frequency of major wounds is lower; (5) the availability of medical personnel and means of evacuation is higher; (6) the proximity to high-level trauma hospitals is closer; and (7) the transport time is shorter. There is not enough data concerning the best management of wounds during a low-intensity conflict. It is not clear whether the principles of wound care should be similar to those of wartime injuries or to peacetime injuries.

In a recent study, the injury data regarding Israel Defense Forces (IDF) casualties during the first 19 weeks of the events was analyzed by the IDF Medical Corps. Ninety-six of the 356 IDF casualties during the first four months of the events were admitted or killed. Bullets were the most common cause of injury (63.5\%). Fragments and explosives accounted for $14.6 \%$ of injuries, stones and sling-thrown marbles accounted for $9.4 \%$ of injuries, and $12.5 \%$ of injuries were due to miscellaneous causes. The most commonly injured body regions included the head, face, and neck (54.2\%), and the limbs $(50.0 \%)$. The trunk was injured in $25 \%$ of the cases, and $4.2 \%$ of the injuries were classified as external. A total of $83.8 \%$ of the casualties were evacuated by ambulances and the rest were evacuated by air. All casualties, except for one, arrived at the hospital within 1.5 hours after the injury. Seventy-five percent of the injured were evacuated to trauma centers, and the rest were evacuated to other hospitals. Most of the soldiers either were mildly injured or killed; few suffered severe injuries. ${ }^{4}$

Hamouda et al suggest that missile wounds in this low-intensity conflict in Gaza are similar to war wounds due to the high number of casualties and the fact that some of them were treated in temporary hospitals under circumstances similar to those during wartime. However, the casualties with minor wounds in the extremities were treated according to a peacetime, wound care protocol. The authors address the question as to whether minor surgical interventions of Grade-1 missile wounds in the extremities would be sufficient to prevent wound infections in these conditions. Hamouda and colleagues registered the rate of infection of the extremities treated with minimal surgical intervention. One hundred fourteen patients with Grade-1 wounds (according to the Red Cross Classification of war wounds) $)^{5}$ were treated according to a standardized regime that included superficial, minor surgical revision of the inlet- and the outlet-openings and antibiotic treatment. After one week, the rate of infection was $10 \%$, and after six weeks, the rate of infection was zero. 
In the current study, the rate of infection was 2-5 times higher than the rate reported in previous studies where civilian gunshot injuries were treated with limited surgical intervention. In these studies, the rate of infection was reported to be $2 \%$ to $4 \%$, and the infection rate has not been influenced by antibiotic treatment. ${ }^{6-9}$ In a report from Afghanistan, 15 causalities with Grade-1 wounds were treated conservatively by cleaning and dressing the wound, and penicillin was administered intravenously for one day and orally for four days. Two patients $(13 \%)$ developed a superficial abscess, ${ }^{10}$ similar to the rate of infection found in the current study. Most of the causalities arrived to the hospital 24-48 hours after being wounded. More work is needed to identify war wounds that can be treated conservatively.

Hamouda and colleagues treated all of the patients with antibiotic prophylaxis. Protocols for antibiotic prophylaxis in the treatment of fractures caused by gunshots have not been delineated clearly in the literature. Using antibiotic therapy to treat these fractures is predicated based on the muzzle velocity of the weapon used to inflict the fracture. A general consensus has been reached regarding the requirement of at least 24 hours of intravenous antibiotic treatment in fractures caused by high-velocity weapons, in conjunction with the appropriate wound and fracture care. Similarly, in fractures caused by shotguns, thorough wound debridement and 24-48 hour administration of intravenous antibiotics is necessary. However, in fractures caused by low-velocity weapons, there is not a preponderance of evidence demonstrating that there is a distinct advantage to using antibiotic prophylaxis in these injuries. ${ }^{11}$

It should be emphasized that the current study only included Grade- 1 wounds in the extremities. Complex wounds, wounds in other parts of the body, and patients with diabetes and other chronic illnesses were excluded from the study. Therefore, conclusions only are relevant for Grade-1 wounds in the low-intensity conflict environment.

The humanitarian efforts made by Hamouda et al in treating all these casualties and their efforts in collecting and analyzing the data are appreciated. Research is the only way to advance knowledge, and more scientific work must be done to develop new concepts in the field of military medicine. However, we believe that prospective studies that examine new, therapeutic concepts must be performed only after the approval of a Helsinki Committee, and that informed consent must be approved by the casualties in order to participate in a prospective study.

Hamouda and colleagues conclude that minimal surgical treatment of missile injuries to the extremities can be an alternative treatment in situations with a high number of casualties and limited resources. However, as the authors stated, the study has several limitations. It is an uncontrolled, non-randomized study, and the results are drawn from a small, selected body of material. Data concerning systemic signs of infection, such as fever or leucocytosis, are missing, which makes it difficult to assess the significance of the wound infections.

Moreover, the rate of infection in this study was found to be 2-5 times higher than the rate found in the literature of civilian gunshot wound cases that were treated conservatively, and similar to wartime gunshot wounds treated conservatively. These facts make it difficult to support the conclusion of this study.

It is agreed that further studies should be performed where patients are randomized to different treatment regimens. Hopefully, peace will come soon and there will be no need for further study.

\section{References}

1. Berko A, Erez E: "Ordinary people" and "death work": Palestinian suicide bombers as victimizers and victims. Violence Vict 2005;20(6):603-623.

2. Kluger Y, Peleg K, Daniel-Aharonson L, Mayo A: The special injury pattern in terrorist bombings. J Am Coll Surg 2004;199(6):875-879.

3. Leiba A, Halpern A, Kotler D, Blumenfeld A, Sofer D, Weiss G, Peres M, Laor D, Levi Y, Goldberg A, Bar-Dayan Y: The case-study of the terrorist bombing in Tel-Aviv Market: Putting all the golden eggs in one basket might save lives. International Journal of Disaster Medicine 2005;2(4):157-160.

4. Lakstein D, Blumenfeld A: Israeli Army casualties in the second Palestinian uprising. Mil Med 2005;170(5):427-430.

5. Coupland RM: The Red Cross Classification of war wounds: The E.X.C.F.V.M. scoring system. World J Surg 1992:16(5):910-917.
6. Woloszyn JT, Uitvlugt GM, Castle ME: Management of civilian gunshot fractures of the extremities. Clin Orthop 1988;226:247-251.

7. Dickey RL, Barnes BC, Kearns RJ, Tullos HS: Efficacy of antibiotics in lowvelocity gunshot fractures. J Ortbop Trauma 1989;3(1):6-10.

8. Geissler WB, Teasedall RD, Tomasin JD, Hughes JL: Management of low velocity gunshot-induced fractures. J Ortbop Trauma 1990;4(1):39-41.

9. Knapp TP, Patzakis MJ, Lee J, Seipel PR, Abdollahi K. Reisch RB: Comparison of intravenous and oral antibiotic therapy in the treatment of fractures caused by low-velocity gunshots. A prospective, randomized study of infection rates.J Bone Joint Surg (Am) 1996;78(8):1167-1171.

10. Bowyer GW: Management of small fragment wounds: Experience from the Afghan border. J Trauma 1996;40(Suppl 3):s170-172.

11. Simpson BM, Wilson RH, Grant RE: Antibiotic therapy in gunshot wound injuries. Clin Ortbop Relat Res 2003;408:82-85. 


\section{Call for Artwork}

The cover design of Prehospital and Disaster Medicine calls for a photograph of relevant artwork.

If you have access to artwork that you think may be appropriate, please submit a slide or high-resolution print (in TIFF or JPG format) to:

Dana Schmidman, Editorial Assistant 3330 University Avenue Madison, Wisconsin 53705 USA E-mail: ds5@medicine.wisc.edu 